\title{
Quality Management Initiatives Indispensable for Revamp Service Delivery of Academic Staff in South East Universities Nigeria
}

\author{
Stanley U. Nnorom \\ Educational Management and policy \\ Nnamdi Azikiwe University, Awka, Nigeria \\ Amanze N. Ikwu \\ Cardiology Department, \\ University Hospitals Plymouth NHS Trust, United Kingdom
}

\begin{abstract}
Introduction: One of the educational problems in most developing nations is the management and administration of inadequate resources budgeted to educational sector. Aim: The study sought to examine quality management initiatives indispensible for revamp service delivery of academic staff in South East universities in Nigeria. Method: Desscriptive survey research design was adopted for the purpose of the study using a sample of 1045 respondents out of the total population size of 5225 academic staff of universities in South East, Nigeria. Primary data was collected through self-administered questionnaires and a response rate of $87 \%$ was obtained. The instruments were validated by the experts, and statistical mean and standard deviation was used in analyzing the research questions while t-test was espoused for the hypothesis. Results and Conclusion: The study concludes that Quality management stratagem and tools has been found to be necessary in enhancing the standard of academic staff service delivery in universities in South East, Nigeria.
\end{abstract}

Keywords: Quality management, Teachers, service delivery, Academic Staff, South East Nigeria

\section{Introduction}

One of the educational problems in most developing nations is the management and administration of inadequate resources budgeted to educational sector. This has increased perception of the need for quality management of human, material and financial resources for the attainment of the nation's education goals. In the field of academics, management of education can be described as the art of working through people for the achievement of the broad educational goals (Anyaogu, 2016). To achieve the educational goals, the manager has to map out strategies, find the people and materials to do the job, assign different people to accomplish different jobs, ensure that these jobs are being done as planned, and report the result of his work to his boss. In coordinating this activity, the manager plans, organizes staff, directs and controls (Ihebereme et al, 2006). Unachukwu (2014) in a brief and clearly expressed manner remarked that, "A major concern of management is to arrange workers into 
units with specified activities to be performed for the purpose of ease of supervision and performance evaluation". According to Mishra (2006) managing educational Institution is "the process of utilizing appropriate materials in such a way to promote effectively the development of human qualities. It includes all those techniques and procedures employed in operating the educational organizations in accordance with established practices. From these definitions, quality management can be simply defined as managerial process through which efforts of members of the educational system are co-ordinate directed and guided towards the accomplishment of the goals of education, by carrying out management functions such as planning, organizing, directing, financing, supervising, monitoring, inspecting and evaluating.

However, educational institutions need to introduce new structures and approaches to management in order to practice management effectively. Quality management is relevant to education because it asserts the centrality of pupil's welfare and development; require schools to engage in long-term planning staff training and development and continuous assessment Olaley (2013). The key personnel within the educational institutions, who play an important part in the implementation of this task and in bringing about transformation within the lives of the individuals, are the teachers. The teacher is regarded as the most important element within the educational program. It is the teacher, who is responsible for putting into practice the educational programs at any stage. It is vital to make an investment in leading to preparation of the teachers in an appropriate manner, so that the individuals, community as well as the entire nation can move forward towards progression (Babajide, 2012). The teachers are required to be well-prepared and possess the essential skills and abilities with the purpose of performing their tasks and functions in an appropriate manner.

Teachers are the mainstay of the educational system because the weight lies on them to bestow and facilitate the acquisition of relevant knowledge necessary for educational goals to be achieved (Eneasator, 2014). It is certitude to note that no education can rise above the quality of its teachers and the quality of teachers, to a large extent, determines the quality of educational output, hence the need for appreciable standard in their service delivery. Every educational system at every level depends heavily on teachers for the execution of its programmes. Maintaining and improving educational standards is only possible through teachers. A teacher is a person who teaches or instructs and provide education for learners thereby helping them to acquire new knowledge and making them useful to themselves and the society. The teacher is a crucial component of any educational system because no organized education can take place without the teachers. The teachers implement educational policies, the curriculum and play significant roles in the attainment of the objectives of any educational system. A teacher's role may vary among cultures, they may provide instruction in literacy and numeracy, craftsmanship or vocational training, arts, religion and civic community roles. These roles make a teacher the greatest aid to learning and the most indispensible entity in the school which should be comprehensively trained and supported to flawlessly and proficiently perform the teaching duty (Osuafor, 2014).

The utilization of teachers to achieve maximum result is dependent on the availability and accessibility of school materials. To aid the utilization of teachers, they should be availed the opportunity for in-service training for career improvement and development. Such in-service training will enable teachers renew their knowledge for effectiveness on their jobs and enable teachers to be efficient and be properly utilized in the school system to fast-track the achievement of the educational goals.. Okendu (2012) asserts that idea that human and material resources are to be assembled together by educational management, within the 
school system for effective teaching and learning cannot be over emphasized. It is supported on this ground that, in secondary schools, the principals play the role of managers and that of supervisors, even instructors and they also participate in teaching activities when necessary. All staff, teaching and non-teaching should be made to realize their responsibilities of improving and developing instruction in the school system. This is possible through harnessing the available resources allocated to the schools to realize the goals of tertiary education. According to National Policy on Education NPE (2004:36), the goals of tertiary institution include to

Develop and instill proper values for the survival of the individual and society.

Contribute to national development through high level relevant manpower training.

Develop the intellectual capability of individuals to understand and appreciate their local and external environments.

Promote and encourage scholarship and community service.

Acquire both physical and intellectual skills which will enable individuals to be self-reliant and useful members of the society.

Promote national and international understanding and interaction.

The above goals as listed by the National Policy on Education deserve praise and commendation. The education quality, high standard of education is the desire of every nation because of the indispensable roles of education in societal development, socially, politically and economically. Expectations, standard, good and requirements for quality education to be obtained in tertiary education, the government set up National University Commission (NUC) to be the regulatory body of Universities in Nigerian Education. Much effort is being made by the commission to monitor and regulate the curriculum, academic activities, management machinery and infrastructural development with focus on maintenance of quality.

Accordingly, Quality Assurance section is set up in all tertiary institutions with administrative function of ensuring that organizational operations are sustained to an acceptable level of performance, thereby ensuring that quality and standards are maintained. The department ensures cost- effectiveness and working conditions. Most significantly, output of quality graduates with acceptable minimum performance standards at relevant levels of education. There is need for quality in the level of performance and general service delivery of academic staff of Universities. They should be able to play their instructional roles by teaching effectively using modem standard methods such as Information and Communication Services (ICT). Other services that require quality include, meticulous record keeping, offering guidance services and motivation to students, being innovative and creative, models of good social behaviour to students, timely supervision of students' work including projects and teaching practice, being research oriented and professional advancement (Khan,2010). They should be able to work with great care and perseverance towards achieving education goals by exhibiting positive work ethics such as being dedicated regular to classes, committed to covering the course content. They should offer health services when their students become sick. Swearing in and sustaining standards in service delivery of academic staff of universities is determined by effective management. Management encircles all efforts by those in authority towards using available human and material resources to achieve stated goals. For positive standard to be achieved there is need for quality management. This has become necessary 
because of increasing questions and complaints about the low standard of graduates of tertiary institutions in Nigeria.

Akpan et al.(2016) lament the fact that outdated teaching methods such as approach traditional pedagogical in structural approach or lecture method is still predominantly in use, lecturers misuse space and adopt primary method of conveying information (they are slow to adopt technology). He double the efficacy of education in universities which should be a marker of accomplishments and wonders of the college is worth it. Okenwa (2013) observes that many university graduates are found to be lacking necessary skills required of a teacher today. He blamed the dramatically lower number of learning hours in developing countries. Students standing in lecture rooms without being able to take lecture notes impacts negatively on the quality of education. Apart from teaching methods, lecturers are often blamed for poor standard because of their lack of dedication efficiency in quality service delivery. This necessitated Maduewesi and Oguoma (2015) posit that quality and quantity of academic staff as a problem in tertiary institutions in Nigeria. Quality management requires some essential or vital tools for success to be achieved.

\subsection{University Education}

Tertiary education has two meanings (Scott, 2005) as sighted in Babalola (2007), it means the next level after secondary education, and secondly, it signifies the system of institutions that provides post-secondary school courses and also engages in research. These are principally the university. He opines that Nigeria sees tertiary education as "the education given after secondary education in universities, colleges of education, polytechnics, and monotechnics including those institutions offering corresponding courses". Higher or tertiary education is referred to as the education given after secondary education in universities, colleges of education, polytechnics as well as those institutions offering correspondence courses (Nwangwu, 2007). He further asserts that the success of any organization such as higher education is closely related to the quality of the staff that performs tasks necessary to enable goal achievement. Teachers therefore need to be professionally prepared and equipped with necessary skills so as to be of the desired high standard.

\subsection{Statement of the Problem}

Tertiary education is widely conceived in Nigeria today as an indispensable tool for the people's socio-economic advancement, their political survival, and for the fullest realization of their aspirations and potentialities. Teacher education is targeted towards producing the required teaching manpower for the education system, for quality education. Unfortunately, there is majority of poor quality teachers in the education system leading to constant perusal and inquiry by stakeholders in education and general public accusing finger on fallen standard of tertiary education at poor service delivery of academic staff of Universities. The yearning for improvement has led to concern and efforts towards improving the quality of service delivery. The situation has lead to avocation and calls for quality management. This study described significant constituent of quality management for delivery of the service academic staff of tertiary institutions in South East geo-political zone of Nigeria.

\section{Purpose of the Study}

The purpose of the study is to find out the essential or urgent quality management for improving the service delivery of academic staff of tertiary institutions in South East geopolitical zone of Nigeria. 
Specifically, the study sought to achieve the following objectives:

Ascertain the quality management essential for revamp academic staff service delivery in tertiary institutions in South East geo-political zone of Nigeria.

Examine how quality management indispensable in revamp academic staff service delivery in tertiary institutions in South East geo-political zone of Nigeria

\subsection{Research Questions}

The following questions guided this study:

What is the quality management indispensable for revamp academic staff service delivery in tertiary institutions in South East geo-political zone of Nigeria?

In what ways can quality management indispensable be used in revamping academic staff service delivery in tertiary institutions in South East geo-political zone of Nigeria?

\subsection{Hypothesis}

\section{The following null hypotheses are tested at 0.05 level of significance:}

HOl: There is no significant difference between the mean ratings of academic staff of Federal and State Universities the quality management of indispensable for revamping service delivery of academic staff of tertiary institutions.

$\mathrm{HO}_{2}$ : There is no significant difference between the mean ratings of federal and state universities on the ways quality management indispensable in revamping academic staff service delivery in tertiary institutions.

\subsection{Conceptual Framework}

The key terms are hereby explained. They include quality, quality management indispensable, service delivery, academic staff and tertiary institutions.

\subsubsection{Quality}

Quality is a dynamic state associated with products, services, people, processes, and environments that meet or exceed expectations and enhance produce superior values (Goetsch and Davis 2013). Quality in education is what makes learning a pleasure and a joy. Some measures of student performance may be increased by threats, by competitions for grades or by prizes, but the attachment to learning will be unhealthy. It takes a quality experience to create an independent learner. Quality has to do with the way the teaching/learning process is carried forward

\subsubsection{Quality Management}

Quality management ensures that an organization, product or service is consistent. It has four main components: quality planning, quality assurance, quality control and quality improvement. Quality management is focused not only on product and service quality, but also on the means to achieve it (Wikipedia.org). The term quality management is defined by Uzoechina (2016) as a process that involves the dedication of all aspects of managerial tasks towards achieving the highest standards of education needed by beneficiaries of education including higher education institutions, parents, employers and society at large. Quality management is a different way to organize the efforts of people (Uzoezie, 2015). The objective 
is to harmonize their efforts in such a way that not only do people approach their assigned tasks with enthusiasm, but they also participate in the improvement of how the work gets done. Quality management introduces a significant change in the relationship between those who manage and those who actually do the work, Obadara and Alaka (2013). Current methods of management education encourage people to enter management without actually experiencing "life in the trenches", with the result that they not only do not understand what happens there but have little empathy for the people who must cope with the problems that arise when systems and procedures are simply inadequate to the reality of the marketplace.

\subsubsection{Service Delivery}

Service delivery refers to the actual delivery of a service and products to the customer or clients (Lovelock \& Wright, 2002). It is therefore concerned with the where, when, and how a service product is delivered to the customer and whether this is fair or unfair in nature. The service concept defines the "how" and the "what" of service design, and helps mediate between customer needs and an organization's strategic intent. The aim is to get value for cost of education which is massive. According to Stephen and Paul (2019) Service delivery is defined as perceived activities, processes and manner of rendering one's responsibilities and job expectations based on how activities should be carried out or in accordance with established rules and schedule.

\subsubsection{Academic Staff}

Academic staff members are the key resource in higher education institutions (Negash et al, 2014). Academic staffs, also known as lecturers, are the teaching staff as distinct from nonteaching staff. They are category of staff that carry out the task of teaching and learning and other academic activities.

\subsubsection{Tertiary Institutions}

Tertiary education, more commonly referred to as post-secondary education, refers to academic pursuit undertaken after high school. Undergraduate programs include any postsecondary education that takes up to four years to complete, including certificates, diplomas, and associates and bachelor's degrees. Graduate programs typically require prior completion of an undergraduate degree and include diploma, certificate, masters and doctoral degree programs. You can find tertiary education programs at vocational schools, community colleges, technical schools, professional schools, colleges and universities

\section{Method}

The study adopted survey research design. The population of the study comprises 5225 academic staff (2911 federal and 2314 state) of the 5 federal and 5 state universities in South East geo-political zone of Nigeria. A sample of 1,045 academic staff was selected and this represented $20 \%$ of respondents' population. The sample consisted of (645 federal and 400 state) were selected from the entire population in 3 federal and 3 state sampled universities in South East geo-political zone of Nigeria. The instrument used for data collection was a questionnaire designed by the researchers. Rating scale tagged "Quality Management Indispensible for Revamp Service Delivery in Tertiary Institutions (QMIRSDTI)". Draft copies of the instruments were given to three specialists, one specialist from Educational Measurement and Evaluation, and two specialists from Educational Management and Policy at Nnamdi Azikiwe University Awka, for validation. Sixty (60) copies of the instrument were 
distributed to sixty (60) respondents that were chosen from the universities in South South and South West geo-political zones that were outside the study area on two occasions within the space of two weeks for the reliability. The reliability index of the instrument was 0.89 . Mean rating and standard deviation scores were used to answer the research questions while Z-test statistics was used to test the hypothesis at 0.05 level of significance.

The method of data analysis adopted was the questionnaire items that have weighted mean scores that are equal to or above 2.50 are considered "agreed", while when testing the hypothesis, if the z- cal score was higher than the z-criterion (z-crit.) score the null hypothesis was considered "Not Accepted" while if the z-cal score was lower than the t-crit. score, the null hypothesis was considered "Accepted"

\section{Results}

4.1 Research Question 1: What is the quality management indispensable for revamp academic staff service delivery in tertiary institutions in south east geo-political zone of Nigeria?

Table 1: Mean ratings of federal and state academic staff responses on the quality management indispensable for revamp academic staff service delivery in universities in South East Nigeria?

\begin{tabular}{|c|c|c|c|c|c|}
\hline & \multirow[t]{2}{*}{ item statement } & State & & Federal & \multirow[b]{2}{*}{ Decision } \\
\hline & & Mean Std.dev & Decision & Mean Std.dev & \\
\hline
\end{tabular}

$1 \quad$ Clear definition of goals and task

$3.15 \quad 0.64$

Agree $3.03 \quad 0.73$

Agree and monitoring of staff through constant supervision for improved services

2 Developing tools for constant

Agree evaluation of staff performance or service delivery and taking decision timely

$3 \quad$ Putting in place effective information services using modem methods such as information technology

$4 \quad$ Being innovative in problem identification and problem solving and injecting new ideas improvement.

$5 \quad$ Staff motivation by provision of incentives and effective reward system for good and effective reward service 
6 Prioritization of staff development by encouraging in service training and research

Building positive relationship by encouraging team work and synergy of operations

Creating a favourable work environment which ensures security of staff

$9 \quad$ Cutting of costs and avoiding waste of resources

Putting in place regulatory framework practices such as sanctions and enforcement mechanisms to check staff laxity and other staff misconducts Cluster mean
$2.94 \quad 0.80$

Agree $2.84 \quad 0.85$

Agree

$2.57 \quad 0.67$

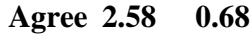

Agree

$2.58 \quad 0.68$

Agree $2.51 \quad 0.61$

Agree

$2.62 \quad 0.78$

Agree $2.62 \quad 0.67$

Agree

$2.58 \quad 0.68$

Agree $2.53 \quad 0.57$

Agree $\begin{array}{lll}\text { Agree } & 2.94 & 0.36\end{array}$

Agree

The result of table 1 show the mean ratings of Federal and State academic staff on the state of quality management indispensable for revamp academic staff service delivery in tertiary institutions in South East geo-political zone of Nigeria. All the items were rated above the cutoff point value of 2.50 in a four- point rating scale.

The above findings signified that the institutions agreed that all the items in the cluster are the indices for quality management indispensable for revamp academic staff service delivery in tertiary institutions in South East geo-political zone of Nigeria recorded a cluster mean score of 2.99 and 2.94 respectively. Both Federal and State tertiary intuitions have the same view.

4.2 Research Question 2: What ways can quality management indispensable in revamping academic staff service delivery in tertiary institutions in South East geo-political zone of Nigeria?

Table 2: Mean ratings of responses of academics staff on the perceived impacts of quality management indispensable in revamping academic staff service delivery in universities in South East Nigeria.

\section{S/N Item statement}

State $(\mathbf{N}=\mathbf{1 2 0})$

Mean Std. dev. Decision Mean Std. dev. Decision

\begin{tabular}{|c|c|c|c|c|c|c|c|}
\hline 11 & $\begin{array}{l}\text { Helps to identify areas of need and } \\
\text { problems (lapses) and proffer } \\
\text { solutions }\end{array}$ & 2.96 & 0.82 & Agree & 2.84 & 0.89 & Agree \\
\hline 12 & $\begin{array}{l}\text { Helps in assessment of cost } \\
\text { effectiveness to get value for massive } \\
\text { investment in education. }\end{array}$ & 2.92 & 0.82 & Agree & 2.81 & 0.86 & Agree \\
\hline 13 & $\begin{array}{l}\text { Provides the needed feedback to } \\
\text { parents and improves public image } \\
\text { about teaching profession }\end{array}$ & 2.58 & 0.71 & Agree & 3.11 & 0.77 & Agree \\
\hline
\end{tabular}


14 Promotes effectiveness and efficiency in teaching and learning for production of quality teachers for the education system methodology and assessment of learning outcome

16 Necessary for taking managerial decisions such as transfer, reform and re-organization.

17 Ensure the achievement of minimum standard, maintenance and improvement in standards

18 Enhances professional practices, scholarship and competence of lecturers for more responsive service

19 Ensures effective use of available resources.

20 Helps to boost the tone of educational institution and entire education system within and outside the country

Cluster mean
$2.67 \quad 0.78 \quad$ Agree

3.03 0.95 Agree

$2.83 \quad 0.43 \quad$ Agree

$2.91 \quad 0.72 \quad$ Agree

2.84

0.74

Agree

3.250 .65 Agree

$3.19 \quad 0.76$

Agree

$2.98 \quad 0.84 \quad$ Agre

$2.98 \quad 0.79$

Agree

2.51

0.61 Agree

$2.53 \quad 0.68$

Agree

$2.90 \quad 0.36 \quad$ Agree

$2.95 \quad 0.38$

Agree

Table 2 shows the mean responses (scores) of academic staff of Federal and State universities on the impact of quality management initiatives indispensable in revamping academic staff service delivery in universities in South East Nigeria. All the respondents were rated above the cut-off point value of 2.50 .

The above findings indicated that both academic staff of Federal and State tertiary institutions agreed that all the items in the cluster are necessary for quality management of service delivery. Academic staff of Federal universities recorded a cluster mean of 2.95 and that of State recorded a cluster mean of 2.90. Comparatively staff of Federal Universities had a higher mean score than staff of State universities but they share the same opinion. However, from the analysis, where cluster means score of 2.90 and 2.95 were obtained, it shows that both federal and state universities (staff) agreed that quality management of staff service delivery is very essential.

\subsection{Test of Hypothesis}

Hol: There is no significant difference between the mean ratings of Federal and State universities' academic staff on the quality management indispensible for revamp academic staff Service delivery in South East universities in Nigeria.

Table 3: Summary of t-test analysis of the difference in the mean ratings of federal and state universities' academic staff on the quality management initiatives for revamping academic staff service delivery in South East universities' in Nigeria.

\begin{tabular}{|c|c|c|c|c|c|c|c|}
\hline Respondents & $\mathbf{N}$ & Mean & STD & DF & $\mathbf{t}$ & Sig (2- tailed & Decision \\
\hline State & 120 & 2.99 & 0.33 & 473 & 1.41 & 0.15 & Not \\
\hline Federal & 355 & 2.95 & 0.36 & & & & rejected \\
\hline
\end{tabular}


Result of table 3 shows that the calculated value (0.15) is greater than the level of significance $(0.05)$ at 473 degree of freedom (dt) the decision rule for the software package for social sciences (SPSS) shows that if the calculated value is less than the level of significance reject the null hypothesis and if otherwise do not reject the null hypothesis. The null hypothesis is not rejected. The acceptance of null hypothesis insinuate that there is no significant difference between the mean ratings of Federal and State Universities' academic staff on quality management initiatives indispensible for revamping academic staff service delivery in South East universities' in Nigeria.

\section{Discussion of Findings}

The findings of research question one revealed that quality management initiatives indispensible for revamping the academic staff delivery in South East universities' in Nigeria that all the component of quality management are essential. The analysis of data collected in research question two sought to find out the perception on the impact quality assurance imperative in improving academic staff service delivery. The result revealed that quality management has impacts in improving the service delivery. Finally the result of the hypothesis revealed that academic staff of both institutions under study agreed quality management imperatives are necessary for improving academic staff service delivery. This in line with Stephen and Paul (2019), who concluded that quality has been the bed rock of the success of any developed and successful establishments around the world while service industries are not exceptions, quality service delivery is more essential in service industry since most products are not physically present but can only be felt or experienced. Academic institutions are real examples of a service industry where quality service delivery determines the success and continuous existence of such establishment. The major determinant of the ongoing concern of any University is the quality of service delivery, since enrollment depends largely among other factors on quality service. To this end, this paper has exposed necessary requirement for quality service delivery and the role of accountants. Considering the models provided and recommendations offered quality service delivery in the university settings should be enhanced geometrically.

\section{Conclusion}

Quality management stratagem and tools has been found to be necessary in enhancing the standard of academic staff service delivery in universities in South East. This is completely transparent and unclouded for educational management, especially in higher institutions. Quality management should be considered a priority by teacher education institutions. The indispensable of quality management which have been identified will help in the revamping and resurgence of our ailing education system.

\section{Recommendations}

The management of university education in Nigeria more especially in South East should be stereotype in providing quality service.

They should be trained and experienced in quality management of staff services, workshops and seminars can enhance in this management.

Effective information and communication technology (ICT) apparatus should be put in place to aid information service.

Academic staffs should be made to assimilate the culture of positive work and social values. 
The management of universities should as a matter of urgency, set up a functioning quality assurance committee for the expected quality to be apprehended.

Government should make funding available and provide necessary material resources, enabling environment which facilitate quality management.

\section{References}

[1] Akpan, C. P. \& Onabe, D. B. (2016). Management of Students' Personnel Services and sustainable secondary education in Calabar education zone of Cross River State, Nigeria. Global Journal of Human Resource Management, 4 (3), 16-26.

[2] Anyaogu R.O. (2016) Educational management in a digital world: Emerging Perspectives. Bon publications. ISBN: 978-34443-6-2

[3] Babajide V.F.T (2012) "Enhancing Cognitive Achievement in Physics: The impacts of Practical Activities". Education and Science Journal.vol2.no1pp1-10.

[4] Babalola J.B. (2007) Reforms and development in Nigeria's tertiary education: focus on the Obasanjo's Administration. NAEP publication ISBN 978-36442-9-5.

[5] Eneasator, G.O. (2014). Improving the pedagogical operational efficiency of Nwafor Orizu Colleges of Education Academic staff through the instrumentally of internal quality

assurance. Being a paper present at a sensitization workshop on quality assurance for lecturers at NOCEN on 1 ffhJanuary, 2019.

[6] Federal Republic of Nigeria (2004). National Policy on Education. Lagos: Nigeria Education Research and Development Council (NERDC)

[7] Goetsch, D. L., \& Davis, S. (2013). Quality management for organizational excellence: Introduction to total quality (7th ed.). Boston: Pearson.

[8] Ihebereme, Chioma I. (2013) "Managing threats to Educational Institutions: an impetus to achieving National Security and Development: a Lead Paper" School of Education Journal of Contemporary Issues (SEJOCI) Vol 1 No. 1, August Enugu: FredOgah Publishers.

[9] Kasule, G.W \&Abooki, N. (2016). Academic staff professional development at Kyambogo University. International Journal of Progressive Alternative education (11)

[10] Khan, M.A. (2010). Evaluating the deming managerial mode of total quality management. Assessed from psu.ed>ist

[11] Lovelock, C. \& Wright, L. (2002) Principles of service marketing and management. Upper saddle River, NJ: Prentice Hall.

[12] Maduewesi, B.U. \&Oguama, H.O. (2015). Quality and Quality of academic staff as a problem in the management of tertiary institutions in F.e. Okafor C.M. Ogbodo\&P.l. Egwusi(Eds). The imperative in tertiary education in Nigeria, Onitsha: West and Solomon.

[13] Mishra, P., \& Koehler, M.J, (2006) Technological Pedagogical Content Knowledge: A Framework for Teacher Knowledge. In Teachers College Record,108 (6), 1017-1054.

[14] Negash R, Zewude S, Megersa R. (2014) the effect of compensation on employee's motivation: In Jimma University academic staff. Basic Research Journal of Business Management and Accounts.

[15] Nwangwu I. 0. (2007). Entrepreneurship in education. Concept and constraints. African Journal of Education and Developmental Studies 4(1), 196 - 207.

[16] Nworgu,B.G(2015). Educational Research Basic issues and methodology: Nsukka: University trust Publishers 
[17] Obadara, E.O. \&Alaka, A.A. (2013). Accreditation and quality assurance in Nigeria Universities. Journal of education and practice 4(8), 34 -41.

[18] Okendu, J.N.(2012a).The impact of school administrative structure and adequate supervision on the improvement of Instructional process. Academic Research Journal.Vol. 2(3)

[19] Okenwa, G.N. (2013). Extent of community participation in the administration of public secondary schools in Enugu State. Unpublished doctorial thesis. Department of educational foundations, Enugu State: University of Science and Technology, Enugu.

[20] Olaleye, F.0 (2013) Principals Organizational Management and Students Academic Achievement in Secondary Schools in Ekiti State Nigeria: Singaporean Journal of Business Economics, And Management Studies Vol.2, No.2.

[21] Osuafor, A. (2014). Standard of education in Nigeria: The role of teachers in excellence in the teaching profession. In C. Umerah, 0, Akaegbobi\&J. Enyisi.teds) Lagos: Trans world Times

[22] Scott P. (2005) Education, higher. In Microsoft Encarta Encyclopedia. Washington, D.C.: Microsoft Corporation.

[23] Stephen, 1. B. \& Paul, K. (2019) IT services delivery accessed from www.searchl'Ioperation.Com

[24] Unachukwu, G. O., and Okorji, P. N. (2014) (Eds.) Education Management: A Skill Building Approach. Anambra: Rex Charles and Patrick Ltd.

[25] Uzoechina, G.O. (2016). Management in the education system. Onitsha: West \&Solomon.

[26] Uzoezie, C.0. (2015).Regeneration of values for the education of the child: A family involvement recipe. First inaugural lecture series of Nwafor-Orizu College of College of Education, Nsugbe $20^{\text {th }}$ November, 2018.

[27] Waldma, D.A. (1994). The contributions of total quality management to a theory of work performance. Academy of Management Reviews 19(3), 510-536. 